\title{
The Relationship between Undergraduates' Background Characteristics and College Experiences and Their Academic Library Use
}

\section{Ethelene Whitmire}

This study examines factors that influence undergraduates' academic library use during the first three years of college. Undergraduates' high school library use, student-faculty interactions, and active learning and engaged writing activities predicted library use for all three years of the study. There was an interesting relationship between undergraduate library use and self-reported and objective critical thinking scores. These findings are useful for the redesign of current academic library services and future research studies on information-seeking behavior.

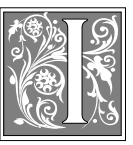

n order to provide adequate resources and to design effective services for undergraduates, academic librarians must understand the factors that influence undergraduate library use. A number of studies have been done to determine those factors. In their study, Paul W. Grimes and Marybeth F. Charters examined several aspects of the college environment that contribute to the amount of time that undergraduates spend in the academic library. ${ }^{1}$ These aspects included:

- demographic characteristics (gender, race, age, alcohol consumption);

- academic aptitude (American College Test [ACT[ score and grade point average [GPA]);

- instruction experiences (study skills or bibliographic instruction);
- college experiences related to their access to the library (jobs, living on campus, member of sorority/fraternity, remote access to library);

- library activities (catalog, periodical, full-text, Internet, books, reserve, interlibrary loan, photocopies, reference, government documents, study hall/social, computer lab).

The authors found that women and African American and other minority undergraduates spent more time in the library, as did undergraduates with lower ACT scores and those who lived on-campus. Undergraduates who worked fulltime and attended a bibliographic instruction session spent less time in the library. It is hoped that these undergraduates now know how to use the library more efficiently. Three library activities appeared to influence the amount of time that un-

Ethelene Whitmire is Assistant Professor in the School of Library and Information Studies at the University of Wisconsin-Madison; e-mail: ewhitmire@facstaff.wisc.edu. 
dergraduates spent in the library: using it as a place to study, using it as a place to socialize, and using it for its reference services.

A study by Qun G. Jiao and Anthony J. Onwuegbuzie investigated the reasons that undergraduates used the library. One aspect of this study specifically examined the relationship between reasons for library use and frequency of library visits. ${ }^{2}$ The authors found that older undergraduates, male undergraduates, nonnative English speakers, undergraduates who lived near the library, undergraduates who preferred to study alone, and undergraduates who had lower levels of library anxiety reported more frequent library use. Five reasons affected frequency of library use: to study for a test, to read current newspapers, to read own textbook, to use computerized indexes and online facilities, and to meet friends.

In his study at a Canadian university, A Paul Williams also examined the factors that influence undergraduate library use, including:

- student characteristics (e.g., gender, first language, prior education, age);

- program characteristics (e.g., program type, field of study, library use required of course, library orientation, library discussed in class);

- perceptions of library services (e.g., inadequate collections, limited weekend access, library hours, lack of staff, did not know how to use the library, did not know how to get the card). ${ }^{3}$

Williams defined library use as using study areas, using photocopiers, borrowing books, reading periodicals, asking for staff assistance, and using reserve collections. The results of the regression analysis indicated that the most important factor contributing to library use was program characteristics (33\% of the variance in total library use), followed by perceptions of the library ( $11 \%$ of the variance). Student characteristics accounted for five percent of the variance.

Finally, in his 1988 dissertation, Charles B. Harrell evaluated the relationship between various student character- istics and undergraduate academic library use. ${ }^{4}$ This study defined library use as number of books borrowed. The personal and academic characteristics of undergraduates included: gender, age, secondary school attended, parents' occupation or education, standardized test scores, class standing, academic major, credit hour enrollment, grade point average, extracurricular activities, distance of residence from the library, and hours of employment. Five variables influenced library use: hours spent on campus, credit hour enrollment, gender, grade point average, and academic major.

\section{Purpose of This Study}

Although a few studies examined the factors that influence undergraduate library use, no study examined these factors longitudinally. The purpose of this study is to answer two key research questions:

- What factors influence undergraduate academic library use?

- Do the factors influencing undergraduate academic library use change during college?

\section{Methods}

\section{Data Source}

This study is a secondary analysis of data obtained from the National Study of Student Learning (NSSL). The NSSL sought to "expand knowledge about college impact by examining the influence of academic and nonacademic experiences on (a) student learning, (b) student attitudes about learning, (c) student cognitive development, and (d) student persistence. ${ }^{\prime 5}$ The NSSL consisted of several survey instruments. The College Student Experiences Questionnaire (CSEQ) supplied information about undergraduate college activities and learning outcomes (e.g., self-reported critical thinking). Another instrument, the National Center on Postsecondary Teaching, Learning, and Assessment (NCTLA), provided additional information about undergraduate college experiences and background characteristics. The Collegiate Assessment of Academic Proficiency (CAAP), a thirty- 


\begin{tabular}{|lcc|}
\hline \multicolumn{3}{|c|}{$\begin{array}{c}\text { TABLE 1 } \\
\text { The Gender Distribution } \\
\text { of the Sample }\end{array}$} \\
\hline \hline Gender & Number & Percentage \\
\hline Female & 682 & $65 \%$ \\
Male & 364 & $35 \%$ \\
\hline Total & 1,046 & $100 \%$ \\
\hline
\end{tabular}

two-item instrument designed by the American College Test (ACT) program, measured undergraduate critical thinking ability (e.g., the ability to clarify, analyze, evaluate, and extend arguments).

\section{Subjects}

The 1,046 participants in this study were selected from the original sample of 3,840 undergraduates. These students participated in all stages of the data collection process during the 1992-1995 academic school years. These undergraduates attended eighteen different four-year institutions throughout the United States. The majority of the undergraduates were female, traditional aged (e.g., nineteen years old), and white/Caucasian, although there were a large number of undergraduates of color in the sample. Other background characteristics included information about the undergraduates' high school library use and their initial critical thinking scores upon college entry. The majority of the undergraduates in the sample did not spend much time studying in the high school library (see tables 1-4 for additional information). Undergraduates' initial critical thinking scores during the fall 1992 term ranged

\begin{tabular}{|c|c|c|}
\hline \multicolumn{3}{|c|}{$\begin{array}{c}\text { TABLE } 3 \\
\text { The Racial/Ethnic Distribution of } \\
\text { the Sample } \\
\end{array}$} \\
\hline Race & Number & Percentage \\
\hline White/Caucasian & 624 & $59.7 \%$ \\
\hline Students of color & 422 & $40.3 \%$ \\
\hline Total & 1,046 & $100.0 \%$ \\
\hline
\end{tabular}

\begin{tabular}{|c|c|c|}
\hline \multicolumn{3}{|c|}{$\begin{array}{c}\text { TABLE } 2 \\
\text { The Age of the Sample during } \\
\text { Freshman Year } \\
\end{array}$} \\
\hline Age & Number & Percentage \\
\hline 21 years old or less & 1,003 & $96 \%$ \\
\hline Older than 21 & 43 & $4 \%$ \\
\hline Total & 1,046 & $100 \%$ \\
\hline
\end{tabular}

from a low of forty-nine to a high of seventy-three (the range was forty to eighty). The mean critical thinking score of the sample was sixty-four.

\section{The strongest relationship was between undergraduates' engaged writing activities and their academic library use.}

\section{Measures}

Two sets of variables were examined to determine the factors that influence undergraduate academic library use: (1) background characteristics, and (2) college experiences. Figure 1 displays the variables representing these independent variables.

Scales were created for the following college experiences by adding the items in each category together to create one construct to represent a particular college experience: student-faculty and peer interactions, engaged writing and active learning activities, self-reported critical thinking, and academic library use. Figure 2 provides more details about the items comprising each construct.

Table 5 presents the alpha reliabilities of the scales for each year of the study to

\begin{tabular}{|lcr|}
\hline \multicolumn{3}{|c|}{$\begin{array}{c}\text { TABLE } 4 \\
\text { Time Spent Studying in the High } \\
\text { School Library }\end{array}$} \\
\hline \hline High School & & \\
Library Use & Number & Percent \\
\hline Never & 257 & $24.6 \%$ \\
Occasionally & 562 & $53.7 \%$ \\
Often & 169 & $16.2 \%$ \\
Very often & 58 & $5.5 \%$ \\
Total & 1,046 & $100.0 \%$ \\
\hline
\end{tabular}




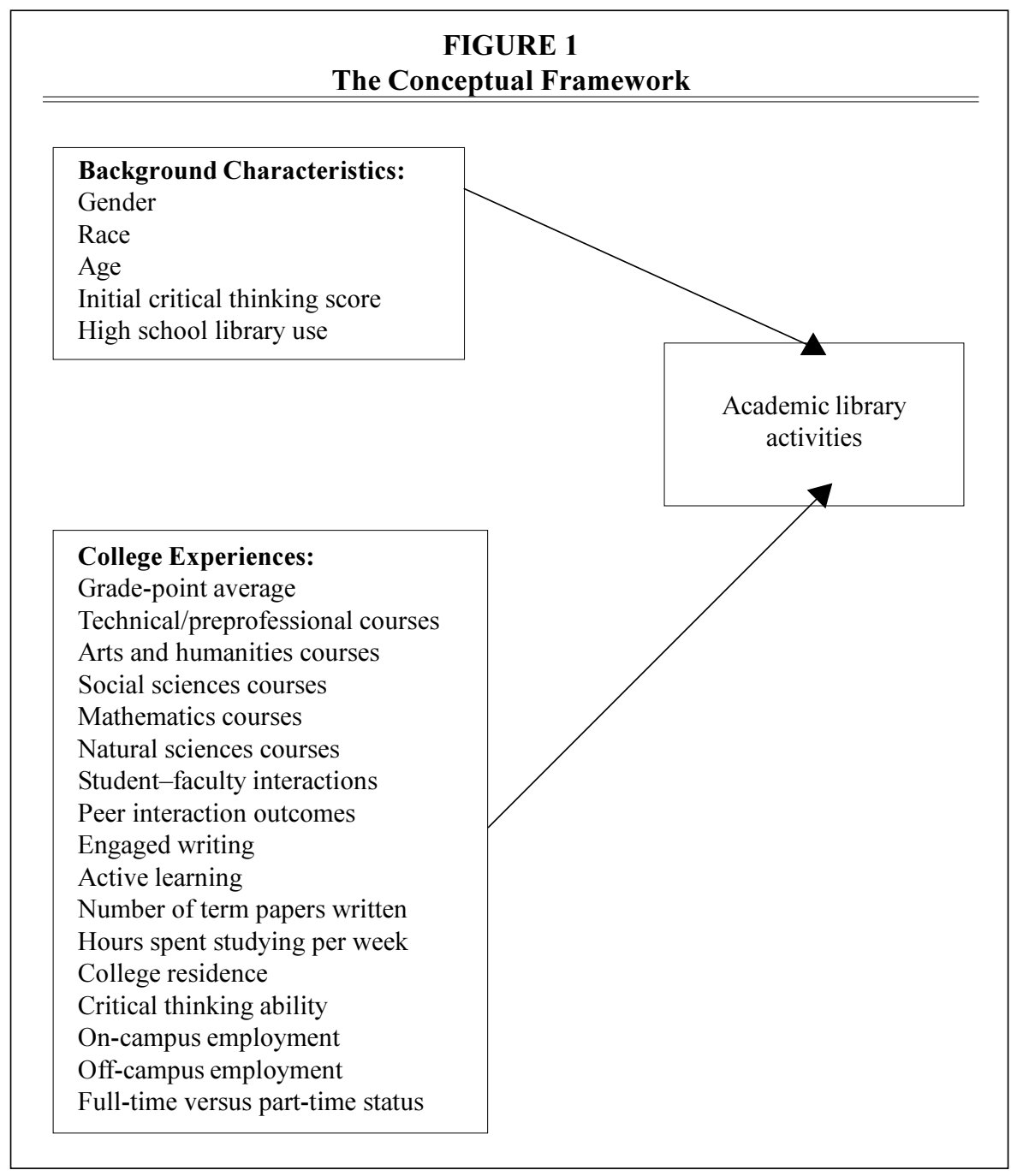

determine how well each scale measures the construct it purports to represent. The alpha reliability coefficients range from .79 to .91 . This range indicates that these scales are valid measures of the constructs in this study.

Table 6 displays the means, standard deviations, and definitions of all of the measures in the study.

\section{Analyses}

Data analysis was conducted in several stages. First, the means and standard deviations of all the variables in the study were calculated. Second, Pearson's prod- uct moment correlations were calculated to determine the relationship among undergraduates' background characteristics, college experiences, and academic library use. Finally, multiple regressions were run for each year of the study to determine which background characteristics and college experiences influenced undergraduate academic library use.

\section{Results}

An examination of the means and standard deviations in table 6 reveals that throughout the three years of the study, undergraduates engaged in library expe- 
riences only occasionally. Although library use increased each year from 2.07 to 2.10 to 2.14 , the mean of the academic library experiences variable never rose to the level of undergraduates engaging in library activities often or very often.

Table 7 shows the results of the correlation analyses determining the strength of the relationship among undergraduates' background characteristics, college experiences, and academic library use during their first three years of college. A number of variables correlated to undergraduate academic library use during the freshman year. The strongest relationship was between undergraduates' active learning and engaged writing activities (tied) and their academic library use. The weakest relationship was between gender and library use. Female undergradu-

\section{FIGURE 2}

Factor Scales

\section{Student-faculty interactions:}

Talked with faculty member; asked for information related to a course; visited informally after class; made office appointment with faculty; discussed term paper/ project with faculty; discussed career plans with faculty; asked for comments/criticism about work; had coffee, cokes, snacks with faculty; worked with faculty on research project; discussed personal problems with faculty

\section{Peer interaction outcomes:}

Peers affect intellectual growth, peers affect ability to analyze, peers affect ability to write, peers affect understanding numerical concepts, peers affect reading ability, peers affect expressing ideas orally, peers affect pursuing ideas from class, peers affect understanding scientific concepts, peers affect interests in new things, peers affect ability to work with others, peers affect success in college

\section{Engaged writing:}

Used dictionary or thesaurus; thought about grammar, etc. while writing; wrote rough draft and revised it; spent five or more hours writing a paper; asked others to read something you wrote; referred to style book or grammar manual; revised paper two or more times; asked instructor for advice on writing; made appointment to talk about criticism; submitted writing for publication

\section{Active learning:}

Took detailed notes in class, participated in class discussions, underlined major points in readings, saw how facts and ideas fit together, thought about practical applications, integrated ideas from various sources, summarized major points and information, explained material to another student, made outlines from notes or readings, did additional readings

\section{CSEQ critical thinking:}

Gains in the ability to put ideas together, gains in the ability to think analytically, gains in the ability to learn on one's own

\section{Academic library use:}

Used computers for library searches, used indexes to journal articles, developed a bibliography, used card catalog or computer, asked librarian for help, read in reserve or reference section, checked out books, checked citations in things read, read basic references or documents, found material by browsing in stacks 


\begin{tabular}{|c|c|c|c|c|}
\hline \multicolumn{5}{|c|}{$\begin{array}{c}\text { TABLE } 5 \\
\text { Internal Consistency (Alpha Reliabilities) for All Scales }\end{array}$} \\
\hline Factor & $\#$ of tems & 1993 & 1994 & 1995 \\
\hline Student-faculty interactions & 10 & .89 & .90 & .91 \\
\hline Peer interaction outcomes & 11 & .90 & .90 & .91 \\
\hline Engaged writers & 10 & .85 & .87 & .88 \\
\hline Active learners & 10 & .84 & .84 & .86 \\
\hline CSEQ critical thinking self-reports & 3 & .80 & .79 & .82 \\
\hline Academic library experiences & 11 & .86 & .86 & .86 \\
\hline
\end{tabular}

ates used the library more often. Other variables correlated with freshman-year academic library use were (in descending order of importance): student-faculty interactions, self-reported critical thinking, peer interactions, high school library use, lower initial critical thinking scores, undergraduates of color, hours spent on schoolwork, number of term papers written, lower critical thinking scores, and fewer social sciences courses.

\section{Enrollment in natural sciences, mathematics, and technical and professional courses did not impact library use.}

Many variables correlated with undergraduate academic library use during the sophomore year. Again, the strongest relationship was between undergraduates' engaged writing activities and their academic library use. The weakest relationship was between enrollment in social sciences courses and library use. Other variables correlated with sophomore-year academic library use were (in descending order of importance): active learning activities, student-faculty interactions, high school library use, peer interactions, self-reported critical thinking, number of term papers written, lower critical thinking scores, arts and humanities courses, undergraduates of color, hours spent on schoolwork, and gender (female).

Several variables correlated with undergraduates' academic library use during the junior year. For the third year in a row, the strongest relationship was between undergraduates' engaged writing activities and their academic library use. The weakest relationship was between working off-campus and library use. The more hours that undergraduates worked off-campus, the less likely they were to engage in academic library use. Other variables correlated with junior-year academic library use were (in descending order of importance): active learning activities, student-faculty interactions, selfreported critical thinking, peer interactions, number of term papers written, high school library use, arts and humanities courses, hours spent on schoolwork, social sciences courses, lower critical thinking scores, and living on-campus.

Table 8 reports the results of the regression analyses for all three years of the study. The background characteristics and the college experiences entered the regression equations in one block in order to determine which factors predicted undergraduate academic library use. Several factors predicted freshman-year academic library use (in descending order of importance): active learning activities, engaged writing activities, student-faculty interactions, high school library use, and race (students of color). A number of factors predicted sophomore-year academic library use (in descending order of importance): engaged writing activities, active learning activities, high school library use, and student-faculty interactions. Many factors predicted junior-year academic library use (in descending order of importance): engaged writing activities, student-faculty interactions, active learning activities and high school library use (tied), off-campus employment (negative 
TABLE 6

Means and Standard Deviations of the Measures in the Study

\begin{tabular}{|c|c|c|c|c|c|c|c|}
\hline Variable & \multicolumn{2}{|c|}{ Fall 1992 Mean } & \multicolumn{2}{|c|}{ Fall 1992 S.D. } & \multicolumn{3}{|r|}{ Variable Definition } \\
\hline Age & 18.74 & & & 3.57 & & & Range $17-87$ \\
\hline Gender & .65 & & & .48 & & & $1=$ female, $0=$ male \\
\hline Race/ethnicity & .61 & & & .49 & & & $1=$ white $/$ caucasian, $0=$ student of color \\
\hline High school library use & 2.03 & & & .79 & & & $1=$ never, $2=$ occasionally, $3=$ often, $4=$ very often \\
\hline \multirow[t]{2}{*}{$1^{\text {st }}$ CAAP critical thinking scores } & 63.61 & & & 5.23 & & & Range $=40-80$ \\
\hline & $\begin{array}{c}\text { Spring } \\
1993 \\
\text { Mean } \\
\end{array}$ & $\begin{array}{c}\text { Spring } \\
1993 \\
\text { S.D. } \\
\end{array}$ & $\begin{array}{c}\text { Spring } \\
1994 \\
\text { Mean } \\
\end{array}$ & $\begin{array}{c}\text { Spring } \\
1994 \\
\text { S.D. }\end{array}$ & $\begin{array}{c}\text { Spring } \\
1995 \\
\text { Mean } \\
\end{array}$ & $\begin{array}{c}\text { Spring } \\
1995 \\
\text { S.D. }\end{array}$ & \\
\hline Self-reported grade-point average & 3.27 & 1.11 & 3.30 & 1.04 & 3.35 & 1.03 & $1=\mathrm{C}$ or lower; $2=\mathrm{B}-\mathrm{C}+; 3=\mathrm{B} ; 4=\mathrm{A}-, \mathrm{B}+; 5=\mathrm{A}$ \\
\hline Student-faculty interactions & 1.97 & .54 & 2.06 & .58 & 2.17 & .62 & $1=$ never, $2=$ occasionally, $3=$ often, $4=$ very often \\
\hline Engaged writing & 2.61 & .60 & 2.54 & .63 & 2.48 & .65 & $1=$ never, $2=$ occasionally, $3=$ often, $4=$ very often \\
\hline Peer interaction outcomes & 2.33 & .66 & 2.54 & .65 & 2.58 & .66 & $1=$ never, $2=$ occasionally, $3=$ often, $4=$ very often \\
\hline Number of term papers written & 3.12 & 1.02 & 2.92 & 1.04 & 2.98 & 1.08 & $\begin{array}{l}1=\text { none; } 2=\text { fewer than } 5 ; 3=\text { between } 5 \text { and } 10 ; \\
4=\text { between } 10 \text { and } 20 ; 5=\text { more than } 20\end{array}$ \\
\hline Active learning & 2.78 & .54 & 2.81 & .54 & 2.84 & .55 & $1=$ never, $2=$ occasionally, $3=$ often, $4=$ very often \\
\hline Full-time versus part-time enrollment & .98 & .12 & .97 & .17 & .96 & .20 & $1=$ full-time $; 0=$ part-time \\
\hline Campus housing & .65 & .48 & .65 & .48 & .68 & .47 & $0=$ no, $1=$ yes \\
\hline
\end{tabular}


TABLE 6 (CONT.)

Means and Standard Deviations of the Measures in the Study

\begin{tabular}{|c|c|c|c|c|c|c|c|}
\hline & $\begin{array}{l}\text { Spring } \\
1993 \\
\text { Mean }\end{array}$ & $\begin{array}{l}\text { Spring } \\
1993 \\
\text { S.D. }\end{array}$ & $\begin{array}{l}\text { Spring } \\
1994 \\
\text { Mean }\end{array}$ & $\begin{array}{l}\text { Spring } \\
1994 \\
\text { S.D. }\end{array}$ & $\begin{array}{l}\text { Spring } \\
1995 \\
\text { Mean }\end{array}$ & $\begin{array}{l}\text { Spring } \\
1995 \\
\text { S.D. }\end{array}$ & Variable Definition \\
\hline $\begin{array}{l}\text { Natural sciences courses } \\
\text { (Astronomy, botany, biology, chemistry, } \\
\text { physics, geology, zoology, microbiology) }\end{array}$ & 1.50 & 1.59 & 1.83 & 2.16 & 1.60 & 2.35 & Number of courses taken during the academic year \\
\hline $\begin{array}{l}\text { Social sciences courses } \\
\text { (Anthropology, economics, geography, } \\
\text { political science, psychology, sociology) }\end{array}$ & 1.63 & 1.33 & 1.94 & 1.74 & 1.78 & 2.01 & Number of courses taken during the academic year \\
\hline $\begin{array}{l}\text { Technical/preprofessional courses } \\
\text { (Drawing, drafting, architectural } \\
\text { design, criminology, education, } \\
\text { agriculture, business, physical therapy, } \\
\text { pharmacy, physical education, nursing, } \\
\text { engineering, computer programming, } \\
\text { audiology/speech pathology, child } \\
\text { and family studies, communications, } \\
\text { or social work) }\end{array}$ & 1.43 & 1.56 & 2.26 & 2.59 & 2.96 & 2.61 & Number of courses taken during the academic year \\
\hline $\begin{array}{l}\text { Mathematics courses } \\
\text { (Pre-algebra, algebra, calculus, } \\
\text { statistics, computer science, } \\
\text { geometry, matrix algebra, accounting, } \\
\text { or business math) }\end{array}$ & 1.32 & 1.20 & 1.34 & 1.63 & 1.18 & 1.92 & Number of courses taken during the academic year \\
\hline
\end{tabular}




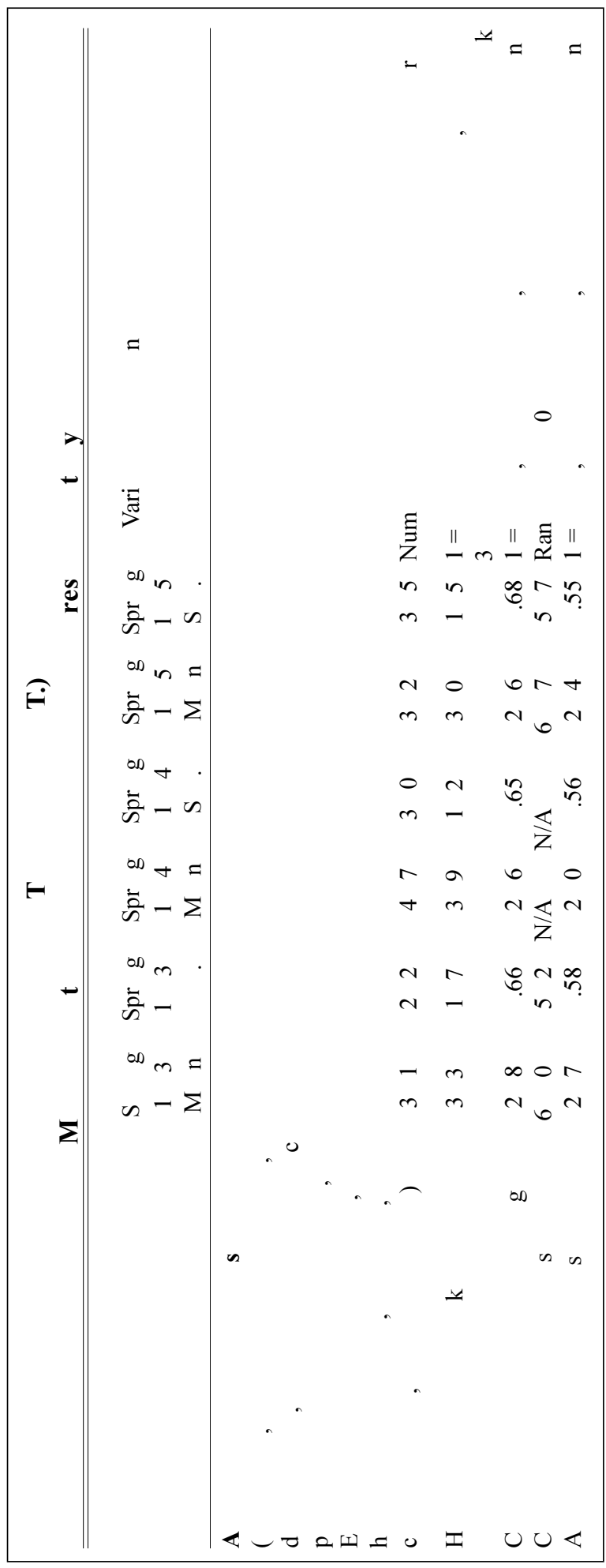

relationship), social sciences courses, self-reported critical thinking, and gender (male). An examination of the $R^{2} \mathrm{~s}$ in table 8 indicates that the variables predicting library use account for 32 to 36 percent of the reasons that undergraduates use the library.

Table 9 provides a summary of the factors influencing students' academic library experiences throughout their first three years of college.

\section{Discussion}

This section describes the implications for the academic library based on the findings. A review of the correlations for all three years of the study reveals several patterns. Although background characteristics such as gender, race, and initial critical thinking scores initially correlated with library use during the freshman and sophomore years, they were no longer statistically significant by the junior year. However, high school library use continued to have a strong relationship with undergraduate academic library use during all three years of the study. The finding that high school library use remained a predictor of undergraduate academic library use after three years in college indicates the importance of assisting undergraduates to develop their library skills during secondary school.

Undergraduates with lower critical thinking scores on the CAAP tests during all three years of the study used the library more often than 


\begin{tabular}{|c|c|c|c|}
\hline \multicolumn{4}{|c|}{$\begin{array}{c}\text { TABLE } 7 \\
\begin{array}{c}\text { Correlations between Background Characteristics, College Experiences, } \\
\text { and Academic Library Activities by Academic Year }\end{array} \\
\end{array}$} \\
\hline & $\begin{array}{l}1993 \\
\text { Academic } \\
\text { Library } \\
\text { Activities }\end{array}$ & $\begin{array}{l}1994 \\
\text { Academic } \\
\text { Library } \\
\text { Activities }\end{array}$ & $\begin{array}{l}1995 \\
\text { Academic } \\
\text { Library } \\
\text { Activities }\end{array}$ \\
\hline \multicolumn{4}{|l|}{ Background Characteristics } \\
\hline Gender & $.072 *$ & $.086^{* *}$ & .046 \\
\hline Age & .029 & .018 & .005 \\
\hline Race & $-.143 * *$ & $-.099 * *$ & -.051 \\
\hline Initial critical thinking & $-.148^{* *}$ & $-.129 * *$ & -.057 \\
\hline High school library use & $.274 * *$ & $.266 * *$ & $.209^{* *}$ \\
\hline \multicolumn{4}{|l|}{ College Experiences } \\
\hline On-campus employment & -.008 & .038 & .021 \\
\hline Off-campus employment & -.004 & -.011 & $-.074 *$ \\
\hline Full-time versus part-time status & .019 & .039 & .025 \\
\hline CAAP critical thinking score & $-.108^{* *}$ & N/A & $-.079 *$ \\
\hline Grade-point average & .041 & -.027 & .034 \\
\hline Number of term papers written & $.109 * *$ & $.174 * *$ & $.217 * *$ \\
\hline Active learning & $.414 * *$ & $.416^{* *}$ & $.421 * *$ \\
\hline Engaged writing & $.414^{* *}$ & $.454 * *$ & $.463 * *$ \\
\hline Student-faculty interactions & $.373 * *$ & $.312^{* *}$ & $.409 * *$ \\
\hline Peer interactions & $.284 * *$ & $.260^{* *}$ & $.270^{* *}$ \\
\hline Natural science courses & -.029 & .003 & .019 \\
\hline Mathematics courses & .041 & -.011 & -.038 \\
\hline Social sciences courses & $-.074 *$ & $.085^{* *}$ & $.129 * *$ \\
\hline Technical/preprofessional courses & .060 & .044 & -.007 \\
\hline Arts and humanities courses & .027 & $.127^{* *}$ & $.172 * *$ \\
\hline Hours spent on schoolwork & $.122 * *$ & $.088^{* *}$ & $.167 * *$ \\
\hline Campus housing & -.026 & .021 & $.075^{*}$ \\
\hline CSEQ self-reported critical thinking & $.307 * *$ & $.232 * *$ & $.333^{* *}$ \\
\hline$* \mathrm{p}<.05 ; * * \mathrm{p}<.001$ & & & \\
\hline
\end{tabular}

did undergraduates who scored higher on the standardized test. However, there was a positive relationship between undergraduates' self-reported critical thinking (e.g., the ability to put ideas together, to think analytically, and to learn independently) and their academic library use. Students with higher self-reported critical thinking used the library more frequently.

Enrollment in arts and humanities during the sophomore and junior years and social sciences courses during all three years of the study impacted under- graduate academic library use. Enrollment in natural sciences, mathematics, and technical and professional courses did not impact library use.

Not surprisingly, undergraduates who spent more hours on their schoolwork also engaged in more academic library activities. The more students studied, the more they used the library.

The variables having the strongest relationship with undergraduate academic library use involved their academic activities. Student-faculty and peer interactions, active learning and engaged writ- 
ing activities, and being assigned term papers impacted library use for all three years of the study.

A review of the regression analyses for all three years of the study reveals that four measures predicted academic library use (e.g., used computers for library searches, used indexes to journal articles, developed a bibliography, used card catalog or computer, asked librarian for help, read in reserve or reference section, checked out books, checked citations in things read, read basic references or documents, found material by browsing in stacks). Active learners (e.g., took detailed notes in class, participated in class discussions, underlined major points in readings, saw how facts and ideas fit together, thought about practical applications, integrated ideas from various sources, summarized major points and information, explained material to another student, made outlines from

\section{TABLE 8}

Academic Library Activities Regressed on Background Characteristics, College Experiences, and Academic Library Activities by Academic Year

\begin{tabular}{|c|c|c|c|}
\hline & $\begin{array}{c}1993 \\
\text { Academic } \\
\text { Library } \\
\text { Activities }\end{array}$ & $\begin{array}{c}1994 \\
\text { Academic } \\
\text { Library } \\
\text { Activities }\end{array}$ & $\begin{array}{c}1995 \\
\text { Academic } \\
\text { Library } \\
\text { Activities }\end{array}$ \\
\hline \multicolumn{4}{|l|}{ Background Characteristics } \\
\hline Gender & -.049 & -.050 & $-.081 * *$ \\
\hline Age & .013 & .017 & -.008 \\
\hline Race & $-.100 * *$ & -.060 & -.042 \\
\hline Initial critical thinking & -.078 & -.016 & .013 \\
\hline High school library use & $.143 * * *$ & $.156^{* * *}$ & $.118^{* * *}$ \\
\hline \multicolumn{4}{|l|}{ College Experiences } \\
\hline On-campus employment & -.011 & .002 & -.052 \\
\hline Off-campus employment & -.033 & .002 & $-.105 * * *$ \\
\hline Full-time versus part-time status & -.013 & .026 & -.040 \\
\hline CAAP critical thinking score & .051 & N/A & -.032 \\
\hline Grade-point average & -.001 & -.071 & -.062 \\
\hline Number of term papers written & .035 & .071 & .069 \\
\hline Active learning & $.189 * * *$ & $.203 * * *$ & $.118^{* * *}$ \\
\hline Engaged writing & $.185 * * *$ & $.249 * * *$ & $.262 * * *$ \\
\hline Student-faculty interactions & $.174 * * *$ & $.101 * *$ & $.172 * * *$ \\
\hline Peer interactions & .038 & .053 & .052 \\
\hline Natural science courses & -.039 & .022 & -.001 \\
\hline Mathematics courses & .042 & -.014 & -.039 \\
\hline Social sciences courses & -.014 & .057 & $.097 * * *$ \\
\hline Technical/preprofessional courses & .026 & .010 & -.001 \\
\hline Arts and humanities courses & -.002 & .051 & .046 \\
\hline Hours spent on schoolwork & .007 & .006 & .060 \\
\hline Campus housing & -.024 & .028 & .014 \\
\hline CSEQ self-reported critical thinking & .065 & -.012 & $.088^{* *}$ \\
\hline $\mathrm{R}^{2}$ & .321 & .319 & .363 \\
\hline \multicolumn{4}{|l|}{$* * * \mathrm{p}<.001 ; * * \mathrm{p}<.05$} \\
\hline
\end{tabular}




\begin{tabular}{|lll|}
\hline \multicolumn{2}{|c|}{$\begin{array}{c}\text { TABLE 9 } \\
\text { Summary of Factors } \\
\end{array}$} & $\begin{array}{l}\text { Influencing Academic Library Experiences by Year } \\
\text { and in Order of Importance }\end{array}$ \\
\hline \hline $\mathbf{1 9 9 3}$ & 1994 & $\mathbf{1 9 9 5}$ \\
\hline Active learning & Engaged writing & Engaged writing \\
Engaged writing & Active learning & Student-faculty interactions \\
Student-faculty interactions & High school library use & Active learning (tie) \\
High school library use & Student-faculty interactions & High school library use (tie) \\
Race (students of color) & & Off-campus job (negative) \\
& & Social sciences courses \\
& & Self-reported critical thinking \\
& & Gender (male) \\
\hline
\end{tabular}

notes or readings, and did additional readings) engaged in more academic library activities during all three years of the study.

Engaged writers (e.g., used dictionary or thesaurus; thought about grammar, etc., while writing; wrote a rough draft and revised it; spent five or more hours writing a paper; asked others to read something you wrote; referred to stylebook or grammar manual; revised paper two or more times, asked instructor for advice on writing; made appointment to talk about criticism; submitted writing for publication) also engaged in more academic library activities during all three years of the study.

In addition, students who interacted with faculty (e.g., talked with faculty member; asked for information related to a course; visited informally after class; made office appointment with faculty; discussed term paper/project with faculty; discussed career plans with faculty: asked for comments/criticism about work; had coffee, cokes, snacks with faculty; worked with faculty on research project; discussed personal problems with faculty) also engaged in more academic library activities during all three years of the study. Finally, high school library use predicted subsequent college library use for all three years of the study.

\section{Implications}

Off-campus work had a negative impact on students' library use during the jun- ior year. This finding is similar to the study in the literature review where students whose full-time employment had a negative impact on the amount of time spent in the academic library. This study only examined library use in the academic library building. Academic libraries can assist undergraduates who do not have time to visit the academic library because of off-campus work obligations by offering electronic access to parts of the collection and digital reference services.

Two findings, the relationships between peer interactions and library use and writing term papers and library use, have implications for the design of academic library services. Academic libraries should consider developing more programs such as the University of Michigan's Peer Information Counselor (PIC) program. ${ }^{6}$ This program and others like it are designed to have undergraduates work the reference desk and assist their peers with information searches. Some programs also include assistance with term papers.

Future research should explore the nature of the relationship between critical thinking and academic library use. This study found a positive relationship between self-reported critical thinking and library use and a negative relationship between objective measures of critical thinking and library use. Moreover, junior-year self-reported critical thinking predicted junior-year academic library use. One question to investigate is, Do 
students with different levels of critical thinking exhibit different library use patterns or information-seeking behavior?

Finally, and most important, a review of the means revealed that the undergraduates in this study collectively engaged in academic library activities only occasionally. An examination of the findings from this study is useful for understanding the factors that influence undergraduates' library activities, but addi- tional research is needed to determine how to increase students' library activities. In addition, the background characteristics and college experiences identified in this study explained only approximately one-third of the reasons that students use the academic library. Future research is needed to determine what other factors influence undergraduates to use the academic library's services and resources.

\section{Notes}

1. Paul W. Grimes and Marybeth F. Charters, "Library Use and the Undergraduate Economics Student," College Student Journal 34 (Dec. 2000): 557-70.

2. Qun G. Jiao and Anthony J. Onwuegbuzie, "Prevalence and Reasons for University Library Usage," Library Review 46, no. 6 (1997): 411-20.

3. A. Paul Williams, "Conceptualizing Academic Library Use: Results of a Survey of Continuing Education Undergraduates in a Small Canadian Undergraduate University," Canadian Journal of Higher Education 25, no. 3 (1995): 31-48.

4. Charles B. Harrell, "The Use of an Academic Library by University Undergraduates" (Ph.D. diss., Univ. of North Texas, 1988).

5. Ernest T. Pascarella, Elizabeth J. Whitt, Amaury Nora, Marcia I. Edison, Linda S. Hagedorn, and Patrick T. Terenzini, "What Have We Learned from the First Year of the National Study of Student Learning?" Journal of College Student Development 37 (Mar. 1996): 182-92.

6. Karen E. Downing, Barbara MacAdam, and Darlene P. Nichols, Reaching a Multicultural Student Community: A Handbook for Academic Librarians (Westport, Conn.: Greenwood Pr., 1993). 